\title{
Activity-Based Life-Cycle Costing applied to an innovative forestry company product portfolio
}

\author{
Achille-B. Laurent * $\mathbb{D}$, Robert Beauregard **(D), \\ Sophie D'amours ***(D) \\ * TransLucid Consulting, translucid.eu \\ ** Laval University, Department of Wood and Forest Sciences, Québec, QC, Canada \\ *** Laval University, Department of Mechanical Engineering, Québec, QC, Canada
}

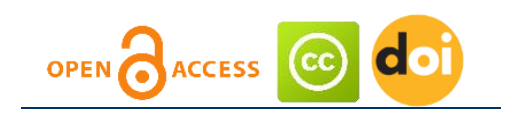

\section{Article history:}

Received: November 18, 2020

1st Revision: February 12, 2021

Accepted: April 08, 2021

JEL classification:
D15
D24
Q23

\section{DOI:}

10.14254/jems.2021.6-1.1

\begin{abstract}
An accounting system helps to provide information for planning and control of production. This article presents a Life Cycle Costing by using an Activity Based Costing approach of an innovative forestry company. In order to perform a cradle-togate assessment the study covers the forest and industrial activities of the forest product processing. The costs of each product in the portfolio are determined by the treatment activities they undergo. The inventory covers several years of activity of the company, which makes it possible to calculate the uncertainty of the average results with Monte Carlo simulation presented in the result section. Based on the results a products portfolio analysis was performed to identify the development progress phases of the mains products to support the product rollover strategy decision.
\end{abstract}

Keywords: product portfolio analysis, activity-based costing, life-cycle costing, engineered wood products.

\section{Introduction}

All companies, regardless of their industrial sector, aim to generate profits. To increase revenues, industrialists can improve the added value of their production. It is also possible to reduce overall costs, such as costs of supply, production and storage. To reduce costs and increase revenues, an accounting management system is required to quantify the realistic production price costs since it will provide system information for planning and production control (Wessels \& Vermaas, 1998).

In traditional accounting, variable costs and fixed costs are spread per unit of production (Nurminen et al., 2009). Thus, only the total costs and the volume of finished products are known (Johnson \& Kaplan, 1991). This information is not always sufficient to implement an accounting system to support the decision-making for the management of the portfolio of products (Rappold, 2006). It is to compensate for this aforementioned shortcoming that Cooper and Kaplan (1988) came up with the method of Activity Based Costing (ABC). Production costs are therefore obtained by summing the costs of activities that generate a product (Maher \& Deakin, 1991). However, this method is known for its complex implementation within a company (Anderson et al., 2002). Due to 
this complexity and the need to integrate the anticipated costs and risks, Emblemsvag (2003) introduced a Life Cycle Costing (LCC) method inspired by the ABC.

The forest industry is recognized a divergent industry, as it generates various products from a single resource (Frayret et al., 2008). In this product portfolio, not all goods have the same costs and value. This implies a distinction between co-products and by-products.

Softwood sawmills transform large volumes that are mainly destined for residential construction (Haygreen \& Bowyer, 1989). Therefore, in this industrial sector, where traditional accounting rules, only lumbers generates value and as a result this is the only value taken into account. Thus, in practice co-products cost are established by the subtraction of the by-products profit from the total production costs. Consequently, the total costs are divided by the production volume in order to achieve a unit cost (Rappold, 2006). This means that co-products cost are variable, depending on the by-products markets.

A traditional accounting system is good enough as long as only one product of the portfolio is valued and the variable costs dominate (Ainsworth et Deines, 2003). With the appearance of new products, such as Engineered Wood Products (EWP) or biofuels, the allocation of costs should be redistributed in a different way than the traditional accounting system. In addition, the sophistication of transformation processes require greater investments, which consequently increase the share of fixed costs of the total costs. Therefore, the traditional costing methods can distort the costs and their allocation (Lere, 2000). This is especially true when some finished products require special treatments (Nurminen, Korpunen, \& Uusitalo 2009).

This paper presents an Activity-Based Life-Cycle Costing (AB-LCC) method applied to an innovative forest company's product portfolio. The innovation of the industrial partner, Chantiers Chibougamau ltee (CCltee), is that it takes advantage of what many see as a long list of disadvantages. CCltee harvests and transforms trees of the boreal forest, which, in spite of their small diameter, have some superior mechanical properties. Therefore, CCltee has invested in the development of a range of EWP, such as glue laminated (glulam) timber, I-joists and cross-laminated timber (CLT) wood panels. These products have one thing in common: they are structural building materials that can be machined to make custom building system components by gluing small pieces of wood together. This raises questions like:

- What is the cost of each activity?

- How should capital resources be allocated to each product in the portfolio?

- What is the actual price cost of each product of the portfolio?

In addition, since the data inventory covert four years of activity, this analysis provides a standard deviation on the cost of each activity from a Monte Carlo simulation based on historical data and therefore also on the cost price of each product. Finally, as discussion we propose an analysis based on technologies investments, products profitability, added value of wood products in order to situate the products of the portfolio on the product life cycle curve.

\section{Literature review}

This section presents a literature review of the accounting methods used in this study, that are mainly LCC and ABC, before summing up the applications of ABC on the forest sector. After a brief history, a critical review details the limits of both approaches, allowing highlighting the interest of Activity-Based Life-Cycle Costing (AB-LCC) method.

\subsection{Life-Cycle Costing}

LCC assessment is intended to calculate the total cost of a product or service, on their life cycle. LCC was developed in the 1960s by the U.S. Defense Department. It wasn't until the 1980s that this methodology was adapted and applied to public investment in the construction sector (Woodward, 1997). More recently, research projects have led to the development of LCC methodologies applied to the construction industry (Gluch et Baumann, 2004).

Many LCC methods have been developed in recent decades. Fourteen different methods were identified from comprehensive literature reviews on the topic (Asiedu \& Gu, 1998; Durairaj et al., 2002; Gluch \& Baumann, 2004). The ABC method is considered by Durairaj et al. (2002) the most promising approach for cost effective analysis in a life cycle perceptive. The literature also presents different critiques regarding LCC approaches. LCCs are usually not based on accounting methods, but rather on cash flow analysis (Emblemsvåg 2003). This implies taking into account exposure to financial risks and in particular the present value of the investment, without being able to provide an indication of the profitability of a product and thus the company. Usual cash flow analyses do not take into account the labor costs and the majority of general costs. In addition, Gluch and Beaumann 
(2004) specified that from its neoclassical approach, LCC could not incorporate uncertainties, irreversible decisions, the commons value and future costs.

\subsection{Activity-Based Costing}

By definition, the ABC method allows detailed analysis of direct and indirect costs associated with a product or a service. In addition, this method has the advantage to highlight the costs origin and causes of variation. Several authors consider the ABC method as strategic management tools, in order to facilitate the decision-making process (Cooper et Kaplan, 1988; Malcom, 1991). The ABC method is also developed to be applied to specific logistics activities (Bokor \& Markovits-Somogyi, 2015; Lin et al., 2001; Pohlen \& Londe, 1994).

Published in 1986 in the Consortium for Advanced Manufacturing international (CAM - I) (Berliner \& Brimson, 1988), the ABC method is part of an engineering process approach. It allows a 'consumed' process costs performance analysis of each activity. According to Schindler (2008), the ABC method can be performed from a customer, product, service, range, unit production, market or business project approach. The aim of applying this method is to improve the overall operation of the company in terms of activities, whether for production, support or structure. This makes it possible to define economic performance indicators for each activity and ensure the follow-up.

The main differences between $\mathrm{ABC}$ and traditional costing systems are in the basic hypotheses. The traditional cost calculation assumes that products consume resources. Costs are distributed at a unit level. The ABC approach considers products as consume activities. Products do not directly use the resources, but activities consume resources. So, costs are distributed by activity, then if necessary by-products. The main purpose of the $\mathrm{ABC}$ is to increase the cost accounting traceability to aid decision support on resource management (Emblemsvag, 2003).

\subsection{Activity Based Costing in forestry applications}

According to Hachez (2006), the ABC method is relevant in the case of a divergent production, such as the forest industry. Despite this perception, we have found only five publications that present case studies using the ABC method applied to the forest industry. Two studies deal with activities in the forest (Nurminen, Korpunen, \& Uusitalo 2009; Posavec et al. 2011). The other three cover only the sawmill activities at the plant (Korpunen, Mochan, \& Uusitalo 2010; Rappold 2006; Wessels \& Vermaas 1998). To our knowledge, there is no publication that covers all the forest company activities. Wessels and Vermaas (1998) pointed out that applying the ABC method on all sawmill activities, in forest and at the plant, would be a strenuous task.

The complexity of implementing the ABC within a company is taken over by several authors, as identified by Anderson et al., (2002). To such an extent that several simplifications have been developed, including how to attribute fixed costs to different activities. In a production plant, time is often an efficient allocation setting regardless the industrial sector. This led to a change in the ABC method by introducing a temporal baseline presented by Kaplan and Anderson (2007). The temporal allocation can be applied on sawmill activities as it was demonstrated by Rappold (2006) and Korpunen et al. (2010) case studies. By using simulation models and cycle times, this approach allows to consider the many logs specifications. That makes it a relevant tool for production planning and control at the operational level. Harvesting and transportation activities can also be costed by a temporal allocation as shown by Nurminen and al. (2009). This case study uses the ABC method to estimate the costs of using subcontractors for each of the harvesting activities (cutting, long shoring and transport).

In their study, Wessels and Vermass (1998) use the historical costs for an ABC on different costs centers of a sawmill. They claim that this approach can help to improve the planning, control and decision-making concerning the management. Both studies, Nurminen and al. (2009) and Wessels and Vermass (1998), agree on the relevance of using the ABC method, but they disagree on the ease of implementing it. While Nurminen and al. (2009) ensure the ABC method implementation is relatively easy, Wessels and Vermass (1998) speak of a laborious and expensive cost system due to the level of detail needed. From our point of view that divergence originates from the significant complexity of the sawmill activities, in comparison with harvesting activities, as shown in the activities description section (section 2). 


\subsection{Relevance of the Activity-based life-cycle costing method proposed by Emblemsvag}

To answer to criticisms of LCC and ABC accounting methods, Emblemsvag (2003) offers a hybrid method that uses the best of both methods: Activity-Based Life-Cycle Costing (AB-LCC). This approach is composed of 10 steps as shown the figure 1. The AB-LCC method by Emblemsvag (2003) has similarities with environmental LCA as defined in the ISO 14044 standard. The retrospective back casting approach allows an analysis based on historical data and this method involves an uncertainty analysis based on a Monte Carlo simulation.

Figure 1: AB-LCC accounting method

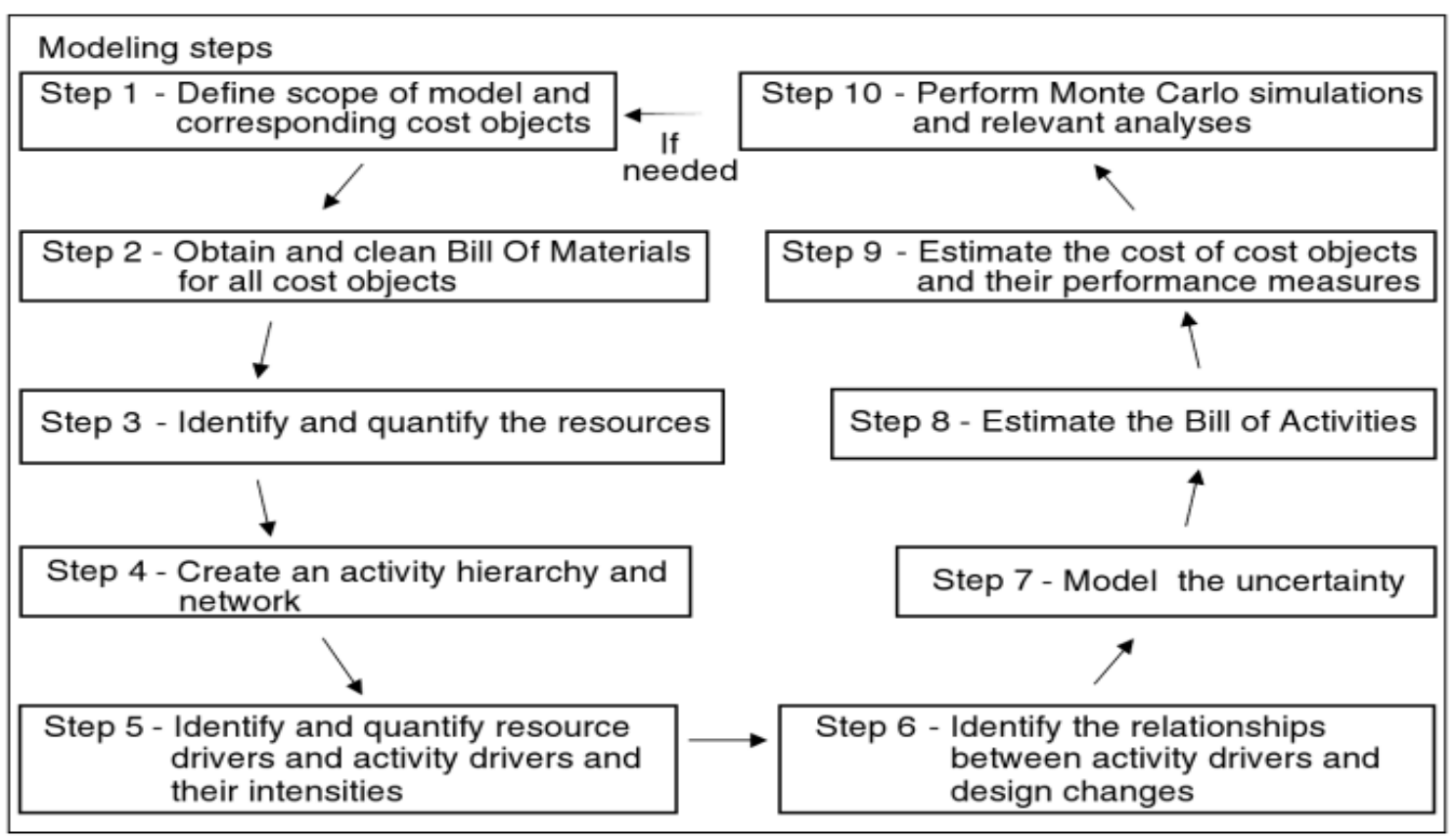

Source: Emblemsvag, 2003

\section{Objectives}

The main objective of this study is to perform an AB-LCC on a forest company product portfolio. Based on the AB-LCC results and statistic data on the wood products of the North American market we provide an analysis on the profitability of the portfolio of products to provide an alternative point of view on the cost center of the forest company management team.

Compared to the ABC approach used by Wessels and Vermass (1998), this analysis is based on historical costs data. The initial inventory covered the activities between 2004 and 2012, but due to a significant change in the manufacturing process of EWP since 2008, we used data from 2009 to 2012. The amendment concerned the size of the wooden pieces. Glulam beams are composed of 1 "x 1 " pieces instead of 2 "x 2" before 2008. This improves the mechanical properties of glulam beams, but it also increases the glue consumption. Therefore, the inventory of data covers all forest and activities at the mill of our industrial partner between 2009 and 2012. Based on these 4 years inventory an annual average was generated to average variable factors, as is common in the forest industry. This also allows estimating the variability of the annual average for an uncertainty analysis. Since it is a model based on historical data, it starts with an inventory of activities. This allows determining the direct costs of each activity. Indirect costs, such as the annualized depreciation costs, financial costs, installation costs and overheads, are redistributed to the corresponding activity. Finally, the cost of each product of the company's portfolio is based on the activities that were carried out for the product on the functional unit basis, a solid and dry cubic meter of wood.

\section{Methodology}

LCC is a method that takes into consideration all costs since the acquisition to the end-of-life treatment (Luo et al. 2009). It is still possible to partition these steps and to analyze only certain phases of the life cycle, as it is practiced for environmental LCA. In the present study, only harvest and transformation processing of wood products steps are considered, thus a cradle-to-gate study, 
thus confined to activities under control of the manufacturer. Nothing prevents the later addition of subsequent "Gate-To-Grave" steps in order to complete the life cycle assessment.

\subsection{Functional unit and allocation}

For this study we used the same functional unit as for the LCA of the same products portfolio (Laurent et al., 2016) which is a cubic meter of solid and dry wood used as production input.

For LCC, some authors recommend the use of allocation based on physical measures (Gluch et Baumann, 2004) as in LCA. In accordance with the recommendations of the products category rules of the forest sector, the allocation is performed on a volume basis (Institut Bauen und Umwelt e.V., 2009; The Norwegian EPD Foundation, 2013). The volume allocation facilitates the understanding for the company, as the traditional accounting is also performed on physical allocation. Even if cost calculation is already on volume base, each product of the portfolio is sold in a different unit, which makes it complex to present the results in this way. We present how these units were converted to a common and single international standard unit below.

Forest activities are reported in commercial volume under the bark in $\mathrm{m}^{3}$. Tops and barks are also transported to the factory. The non-commercial volume has been calculated from the Alemdag model (1982) in between 12 and 14\% of the transported total volume. Volume estimations have been validated by weighing of trucks and by using the dry density of black spruce (Picea mariana (Mill.) B.S.P) (Jessome, 1977). Black spruce represents $85 \%$ of the total volume of harvested species of this forest company.

At the sawmill, the sawed timber volume is calculated in Board-Foot (BF). This specific forest industry unit represents the volume of a board of one foot (or 12 inches) wide and a foot long and an inch thick. As shown in Flann (1962), it is a unit that is not constant, it varies according to species, the provinces, the sawmill but also the stages of transformation. We defined a conversion unit specific to the context of the forest company from the following relations:

A 2" $x 4^{\prime \prime} \times 9^{\prime}$ green Board measure 6 nominal BF.

Actual dimensions are: $1.66^{\prime \prime} \times 3.75^{\prime \prime} \times 110^{\prime \prime}=0.3963 \mathrm{ft}^{3}$

$$
\text { So: } 6 \div 0.3963=15.14 \mathrm{BF} / \mathrm{ft} \mathrm{t}^{3} \text { or } 0.43 \mathrm{BF} / \mathrm{m}^{3}
$$

Once dried and planed lumber this ratio becomes approximately $19 \mathrm{pmp} / \mathrm{ft}^{3}$. Since the dimensions of boards are reduced to $1.5^{\prime \prime} \times 3.5^{\prime \prime}$ and they are cut in between 108 and $110^{\prime \prime}$ length.

$$
6 \div\left(1.5^{\prime \prime} \times 3.5^{\prime \prime} \times 110^{\prime \prime}\right)=19 \mathrm{BF} / \mathrm{ft}^{3} \text { or } 0.54 \mathrm{BF} / \mathrm{m}^{3}
$$

Coproducts as chips, sawdust, and shavings are provided in anhydrous metric ton. We used the over dry density given by Jessome (1977) to determine the volume. The bark is sold in green metric ton. We used the density of the bark of black spruce green provided by Nielson and al. (1985) to convert this into $\mathrm{m}^{3}$.

Wood engineering products, such as glulam and CLT, are sold directly in solid $\mathrm{m}^{3}$. So, no conversions are needed. With regard to wood I-joist, they are measured in length and expressed in feet for each standard dimension of beams. To make the conversion to $\mathrm{m}^{3}$ easier, we used the volume of planed timber used for the I-joist manufacturing process, which is expressed in BF. Therefore, we used the same conversion factor as for dried and planed lumber. The volume of Oriented Strand Board (OSB) bought in Msf 1/16 (thousand feet square with a thickness of 1/16 of an inch), also reported in $\mathrm{m}^{3}$ based on the formulas given by Briggs (1994) was added.

\subsection{Costs allocation}

There are four types of costs, variable, fixed, direct and indirect costs. The ranking of the costs that were used in this analysis are given in Table 1.

Variable costs are all the costs that vary with the level of activity of the company. Direct costs such as raw materials, relate to the production of a single activity. Thus, the variable and direct costs are attributable to an activity. Fixed costs are all costs that evolve independently of the level of activity of the company. Fixed and direct costs are due to a single activity. In order to calculate unit costs, these fixed costs are annualized and divided by the productivity of the activities to which they are attached. 


\section{Table 1: Costs allocation}

\begin{tabular}{cll}
\hline \multicolumn{1}{c}{ Costs } & \multicolumn{1}{c}{ Direct } & \multicolumn{1}{c}{ Indirect } \\
\hline Variables & - Raw materials & \\
& - Salaries of operators and team leaders & \\
& - Energy (consumption) & \\
Fixed & - Consumables (knives, saws...) & - Overhead \\
& - Energy (infrastructure - power) & - Wages of production managers \\
& - Heating of buildings & - Wages of administrative staff \\
& - Production equipment (including & - Business travel \\
& maintenance) & \\
& - Depreciation & \\
& - Salary of the foremen &
\end{tabular}

Indirect costs represent all expenses common to several activities. To allocate indirect costs, it is necessary to apply a method of cost allocation in order to assign them to production activities. We have chosen to achieve a volume allocation, solid and over dry $\mathrm{m}^{3}$. This allows assigning overhead costs to production activities based on usage of the service activities. In this analysis, only the administration is considered a service activity, as shown in figure 2 . The forest company accounting system allows classifying preventive and curative maintenance costs as direct fixed costs since costs are directly attributable to the different production equipment.

\subsection{Equipment amortization}

Amortization calculation follows the model proposed by Bruggeman et al. (2005). Unused capacities are considered to be null and are distributed on costs related to capacity actually used to measure and value the differences business (Gervais et al., 2010). Equation 3 is used to calculate annual amortization.

$$
A_{j}=\frac{e \times p_{j}}{P}
$$

With:

$A_{j}$ - annualized amortization of equipment,

$e$ - purchase price of equipment,

$p_{j}$ - units produced during year $j$,

$P$ - total units produced.

\subsection{Description of the studied activities}

The activities considered in this study cover all the forestry operations and all activities at the sawmill. At the sawmill, activities can also be split in primary processing into lumber products and secondary processing to make EWP and since both are at the same site we did not separate these. The studied activities are shown in the black box in the Figure 2. Many of these activities consist of several sub-activities. Sub-activities are presented in the description of the activities to which they correspond. Additionally, we used the term center costs in the accounting sense, to refer to a group of costs. 
Figure 2: Studied boundaries

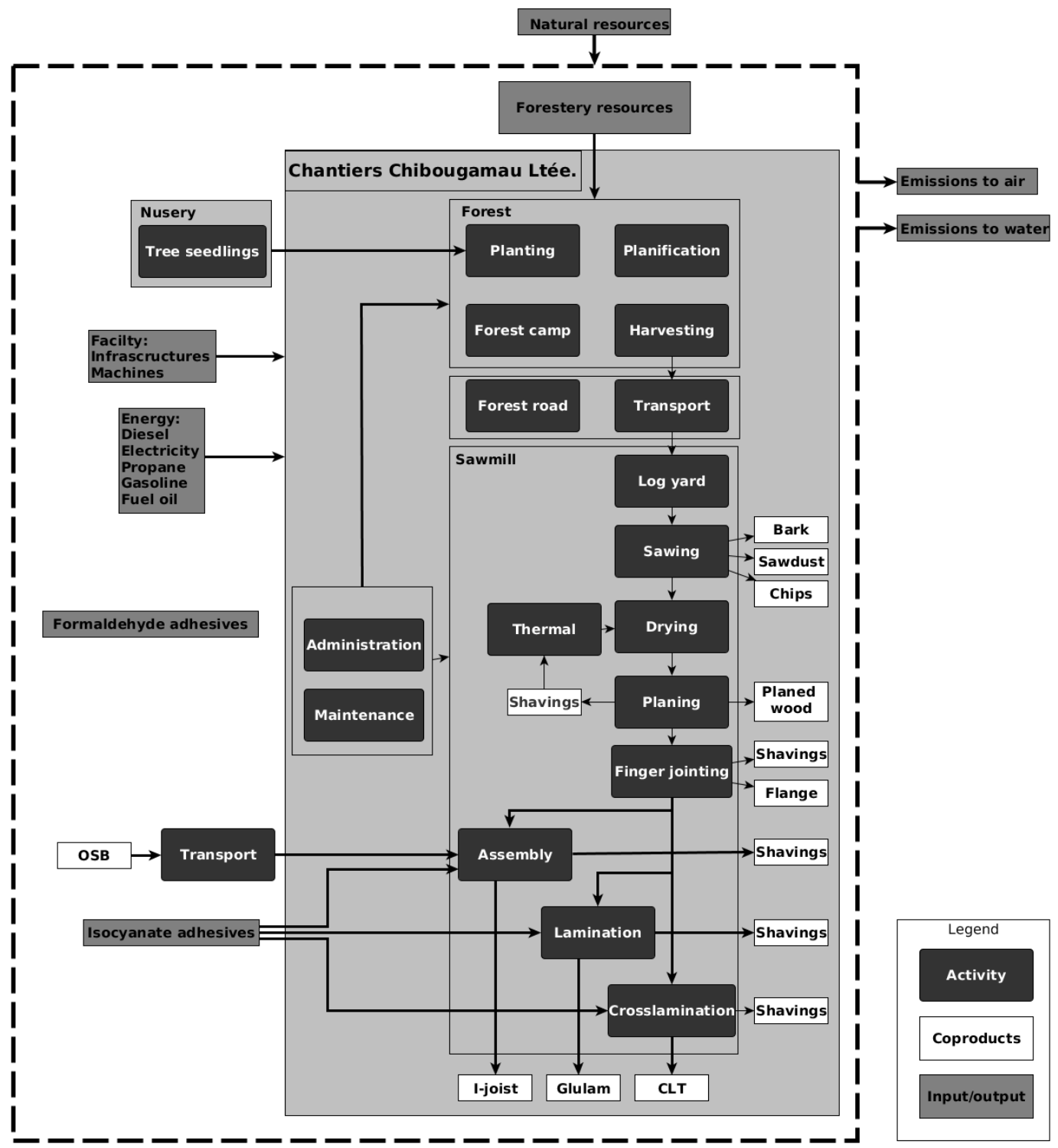

Note: All cradle-to-gate wood products processes, including harvesting and manufacturing. The black boxes represent all activities. The products are in the white boxes.

\subsection{In the forest}

The forest operations can be divided into 4 activities: planting, harvesting, forest road building and forest transportation.

\subsubsection{Planting}

The planting includes all activities related to reforestation. This inclused thinning, land preparation, reforestation and production of plants. The unit used for these activities is usually area. The annual average rate of the annual volume harvested per area unit of studied year is used to convert those costs to the volume allocation.

The production of plants is an exception, as the accounting unit of this activity is the plant. The allocation per cubic meter of wood entering the system is obtained by using Eq. 4:

$$
S_{j}=\frac{\sum q_{j}\left(a_{j} \times n\right)}{V_{j}}
$$

With:

$q_{j}$ - production costs per plant during the year $\mathrm{j}$;

$a_{j}$ - total area harvested in year $\mathrm{j}$;

$n$ - number of plants per unit area; 
$V_{j}$ - total volume harvested year-round j;

$S_{j}$ - total costs of plants per unit of volume harvested in year $\mathrm{j}$.

\subsubsection{Harvesting}

The harvesting activity includes several sub-activities, such as felling, skidding and delimbing. Harvesting costs include fees for public forest harvesting. The accounting unit of all these activities is the annual harvest volume. Harvesting activities are split in 29 direct costs centers such harvest planning, logging camps, movement of machinery, certification fees and contributions to the forests protection (fire and insects fighting organizations). The sum of these fixed costs is reported per unit of volume of annual harvest.

\subsubsection{Construction and maintenance of forest roads}

This activity aims to build and maintain the non-paved road to transport wood logs from forest to the sawmill. This involves costs of machinery, energy, salary of technicians, but also a large amount of materials, such as gravel, dynamite and building materials of bridge constructions. There are 13 cost centers for the variable costs. Fixed costs for the activity of forest roads construction and maintenance are divided into 12 cost centers, such as moving equipment or snow removal.

The accounting unit for the activities of construction and maintenance is in kilometer forest road. For the purpose of this analysis, the costs are calculated per unit of harvested volume. Therefore, as presented in Eq. 5, annual total cost of these sub-activities is divided by harvested volume during the same year.

$$
C_{j}=\frac{\sum b_{j}+\sum m_{j}}{V_{j}}
$$

With:

$b_{j}$ - costs related to the construction during the year $j$;

$m_{j}$ - costs related to the maintenance of road during the year $j$;

$V_{j}$ - total volume harvested during year $j$;

$C_{j}$ - total costs of forest road per unit volume harvested during year $j$.

\subsubsection{Transport}

Transport also includes sub-activities of logs loading in forest road sides and unloading at the lumberyard. There are 9 cost centers for the fixed costs, such as operations supervision and waiting costs.

The trucks are weighed upon their arrival at the sawmill. Costs are calculated on a mass basis and are reported on a unit volume using the density of black spruce, which represents $85 \%$ of the harvested volume. The total costs of this activity are calculated with Eq. 6:

$$
T_{j}=\sum c_{j}+\sum d_{j}+\frac{\sum t_{j}}{M_{j} \times \rho}
$$

With:

$c_{j}$ - loading costs during year $j$;

$d_{j}$ - costs related to the unloading during the yearj;

$M_{j}$ - dry mass total harvested on a basis in year $j$;

$\rho$ - over dry density of black spruce (Picea mariana (Mill.) B.S.P) (Jessome, 1977);

$T_{j}$ - total transportation costs per unit volume harvested year-round $j$.

\subsection{At the sawmill}

At the sawmill plant, there are eight main processing activities, in addition to administrative activities. Since all costs at the plant are directly reported on the volume of treated wood, there is no calculation of allocation needed but volumes have to be converted to the metric system. 


\subsubsection{Log yard}

Operations at the log yard consist of sorting the woodpiles and to supply the sawmill with logs. Variable costs are mainly associated with the energy costs for the use of the handling equipment, and salaries. Fixed costs are mainly equipment maintenance, insurance and snow removal.

All of these activities are recorded in weight. Density was used to express costs in cubic meter of wood solid and dry.

\subsubsection{Sawing}

Sawing consists of three sub-activities: debarking, sawing and sorting. Debarking is to removing the barks of the logs. Sawing cuts the logs in beams. This generates chips and sawdust as co-product. The volume of chips is determined by the input logs diameter and the size of the boards as outputs. Sawing activities have 24 cost centers. The higher costs are salaries, equipment and energy. Sawing production is expressed in the FB and the conversion factor presented in equation 1 was used. Coproducts are accounted on a weight basis, the density of bark and chips from black spruce are used to convert them in $\mathrm{m}^{3}$ over dry and solid (Jessome, 1977).

\subsubsection{Drying}

The drying duration depends on the tree species and the boards dimensions. Once sorted, the boards are placed in dryers. This is the most energy-intensive activity of the sawmill. To reduce energy costs, part of the shavings generated during the planning activity are used as fuel. Drying has in total 20 cost centers. Since the shavings are the main energy source, the salaries and equipment dominated energy costs. The drying accounting unit is BF, a conversion on a dry basis (eq. 2) allows getting the costs allocation in the metric system.

\subsubsection{Planing}

Planing puts the dry boards to commercial dimensions. This activity also generates shavings that are used for energy purposes. The activity is divided into 20 cost centers. The higher costs are wages and machinery. As the previous activities, the accounting unit is the FB. A conversion from equation 2 is used to bring the cost per $\mathrm{m}^{3}$ dry.

\subsubsection{Jointing}

This activity is the first of what could be called the second transformation process of wood products. Also known as jointing, this activity sticks together pieces of wood in their length. Then, a saw cuts to the required dimension of this continuous wood length to feed the subsequent processing steps. A low volume of flange is sold directly. This activity is mainly intended to provide the assembly and glulam lines. The activity costs are composed of 27 cost centers. Although the jointing activity is an automated process, wages costs remain more important than equipment costs. Raw material purchasing costs, including glues, are a significant proportion of the activity costs. The accounting unit of the jointing activity is the linear foot. The volume equivalence was calculated based on the average dimensions of the butted boards.

\subsubsection{Assembly}

This activity is to stick flange and OSB panels to manufacture I-Joist beams. The OSB panels, cut to the required dimension, are purchased from a supplier in the province of Quebec. As can be seen in the mass balance, a small amount of glulam is used for the manufacture superior mechanical properties I-Joist. Assembly activity costs include the flow of glulam as input but without profit margin.

There are 27 cost centers for the assembly activity. Raw material costs are most important for this activity also due to the purchase of the OSB and glues. The production of the I-beams is calculated by linear foot. The volume is calculated through the sized of flanges and the flow of glulam used. 


\subsubsection{Laminating}

Laminating means gluing small pieces of wood together to manufacture glulam beams. Once glued and dried by microwaves, beams are machined in a five axes CNC milling machine of large dimensions beams. This machining allows customizing glulam beams at the plant, in order to be ready-to-assemble building structure directly on the construction site. The activity of laminating counts 113 cost centers that are spread over four production lines and under machining activity. This laminating activity is automated and requires heavy investment. The most important cost centers are facilities and isocyanate glues. The accounting unit of this activity is the cubic foot. A basic unit conversion allows transferring to metric system.

\subsubsection{Cross laminating}

Cross laminating differs from laminating in the size of glued pieces of wood, but especially by the superposition of crossed layers, thus manufacturing CLT panels. The number of layers, varying between three and seven, provide different components of structure of a building. CLT panels can be used as prefabricated walls or floors. A sub-activity of cross-laminating activity is machining to cut openings (doors and windows) according to the specifications of the architect. As with glulam, CLT is a building system component, ready-to-assemble on the construction site. The direct costs of this cross-laminating activity are divided into 24 cost centers. As CLT is recent engineered wood product, the used inventory covers only one year of activity. Just like the laminating, the accounting unit of the laminated cross is the cubic foot. A unit conversion allows reporting the costs per $\mathrm{m}^{3}$.

\section{Results}

From the historical data collected and assumptions that have previously been presented, the costs of each activity were calculated. According to the AB-LCC method, activities are central. Based on the cost of the activities the product's cost price is determined. Thus, the cost of a product is the sum of the costs of all the activities required to produce this product.

\subsection{Material balance}

In the Canadian forest industry the majority of by-products are sold, but a part is used as a source of energy in sawmills (Meil et al., 2009). This is also true in our case study, where parts of the shavings are used to power dryers. Figure 2 shows the volume of the material flows in the studied system. Presented percentages of the total volume are the average of each product generated at the sawmill between 2009 and 2012 .

To avoid cluttering the chart, activities in the forest, including transportation, are grouped in forest operations. Hundred percent of the commercial timber harvested in the forest is sent to the sawmill. The branches are left on the roadside. Similarly, the lumberyard activity is integrated in the sawing. Because the barking and sawing activities in the sawmill are not separately counted, they are grouped into the activity of sawing. 
Figure 3: Mass balance, calculated on a cube meter over dry basis

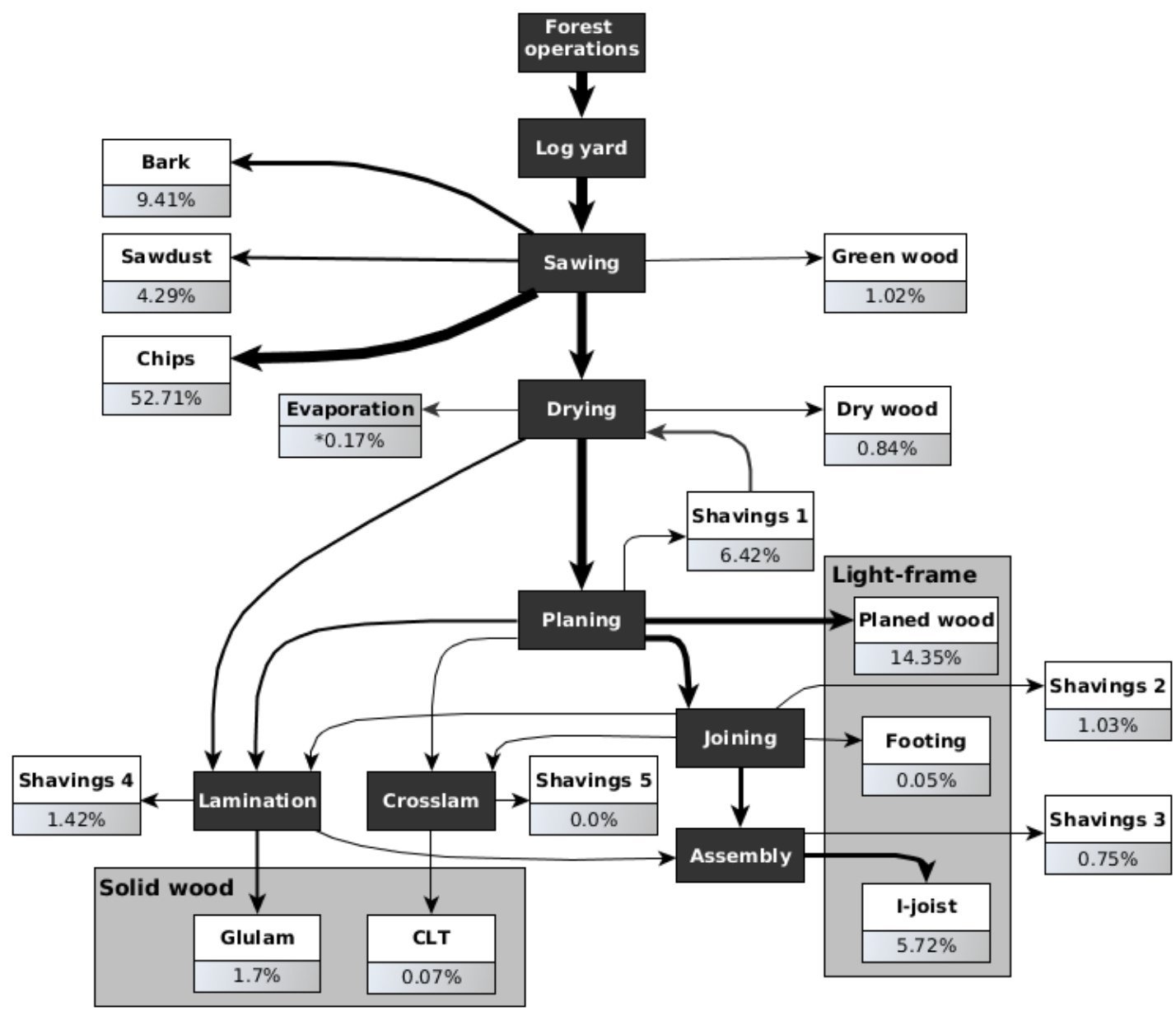

Note: Commodity after drying are somewhat denser because of the effects of shrinkage, resulting in a loss of $0.17 \%$ of the volume.

\subsection{Uncertainty analysis}

The implementation of a management accounting system is of interest for decision support. It is important to evaluate the uncertainties around the results of cost of returned products too. As suggested by Emblemsvag (2003) in the AB-LCC method description, uncertainties of all products costs of the forest company portfolio have been calculated by Monte Carlo simulations.

Although Monte Carlo simulation software is available, an MS Excel spreadsheet is sufficient for our study. We followed the method proposed by Jeges (2008) based on the work of Metropolis and Ulam (1949). This method allows generating random values of the activities costs, which are summed to get the products costs. The cost data for four years allows calculating an average arithmetic to determine the standard deviation of costs of each activity. Since the time period is short others parameters such as inflation, energy price fluctuations was not taken into account. The number of data to calculate the standard deviation by activity type is at least four, but the actual number depends on the number of activities. For example, the activity of harvesting consists of four sub activities, thus 16 data points were used to determine the standard deviation. The first step is to generate random values around the extreme values for each activity. The distribution is considered uniform, so we used the RAND( ) function in Excel. The number of iterations of this operation is determined based on the calculated error, based on Eq. 7:

With:

$$
N=\left(\frac{3 \times b}{\epsilon}\right)^{2}
$$

$b$ - the standard deviation around the historical costs of the activities;

$\epsilon$ - the error of the historical costs of the activities;

$N$ - the number of iterations required for Monte Carlo simulation. 
We have replicated this Monte Carlo simulation method for each activity. Then uncertainties were assigned to the 15 products of the portfolio. The error bars in the Figure 4 represent the uncertainties analysis results. Table 8 shows the number of iterations required to perform Monte Carlo simulations, the deviations and the values of kurtosis and skewness. As shown in the values, the distribution generated by this method is very close to a normal distribution.

\begin{tabular}{lcccccc} 
Table 2: Result of the Monte-Carlo simulation \\
\multicolumn{2}{c}{$\begin{array}{c}\text { Harvesting }+ \\
\text { Sawing }\end{array}$} & Drying & Planing & Jointing & Assembly & Laminating \\
\hline $\boldsymbol{N}$ & 216 & 373 & 322 & 712 & 21 & 2433 \\
$\boldsymbol{\Sigma}$ & 2.08 & 0.71 & 1.5 & 8.22 & 1.5 & 87.6 \\
Kurt & -0.46 & -1.15 & -1.12 & -1.2 & -1.35 & -1.2 \\
Skew & 0.13 & -0.08 & -0.01 & -0.05 & 0.34 & 0.03 \\
\hline
\end{tabular}

Despite a steady increase in harvesting costs, mainly due to fuel prices, and the numerous factors that can influence the forest operations costs, such as weather or technology, the harvesting and sawing activities costs do not vary so much. On the other hand, the largest variability on production costs appear in the EWP manufacturing, particularly the laminating activities. The reasons for these variations are mainly due to fluctuations in the volume of production.

\subsection{Product Portfolio Price Costs}

For confidentiality reasons, products cost results are presented without scale. It is still possible to see the proportions between the different products. Figure 4 also includes the error bars, results of the analysis of uncertainty achieved through a Monte Carlo simulation.

\section{Figure 4: Results of the products portfolio costs, calculated by the activity based life cycle costing method}

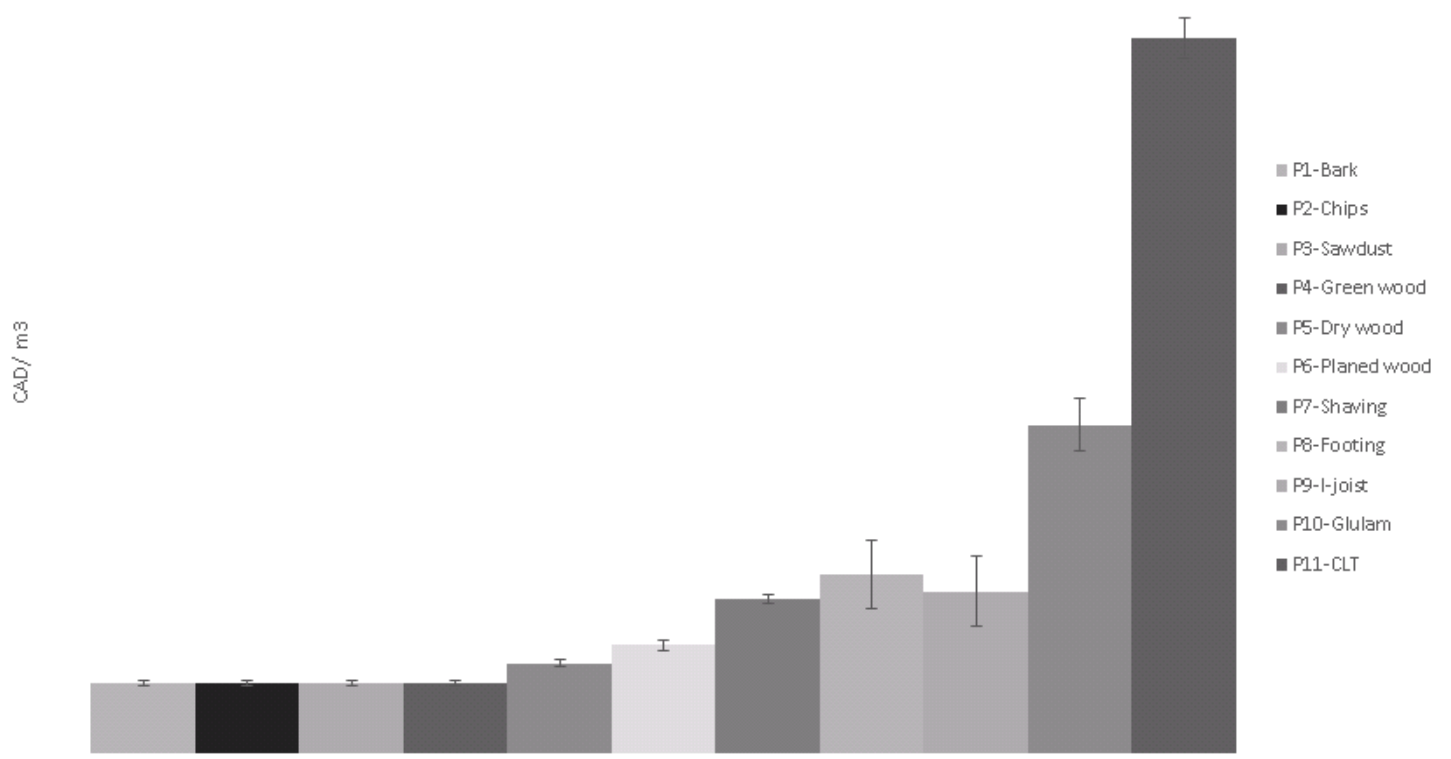

Note: Uncertainty are represented by error bars

The product portfolio costs profile is in the shape of stairs, with the exception of the shavings that are produced in different activities and are grouped in this chart. The more a product undergoes transformation, the more the production cost price increases. This explains the added value term. Results also show a grouping of products generated during the same activity. Since costs are expressed in over dry and solid cubic meter, each of the products of the same activity has the same cost price. I-joist and shavings generated at the assembly activity have a higher cost compared to glulam, due to OSB purchasing costs to an outside supplier.

The costs of CLT are high due to fixed costs and a low production volume. As mentioned, the investments for this new product are important and the production volume is still low since demand is low. On the other hand, glulam is an established technology and production capacity is almost full. Therefore, the cost per unit is two times lower than CLT. 


\subsection{Sensitivity analysis}

The sensitivity analysis is performed to compare the distribution of production with distribution of costs. To verify the results, we identified the most expensive products in the portfolio.

Solid wood products, as glulam and CLT, are high added value wood products. While solid wood production represents $2 \%$ of the volume of CCL activities, it corresponds to $6 \%$ of the total production cost, as shown the figure 3.

Another interesting product is chips to be used in the pulp \& paper industry. Although chips represent more than half of the total volume (53\%), as shown in Figure 6, and contribute 35\% of the total costs. This co-product is sold at market conditions imposed by the pulp and paper industry, and therefore sometimes at a loss.

Figure 5: Comparison between the distribution of costs and production volume of the wood products portfolio
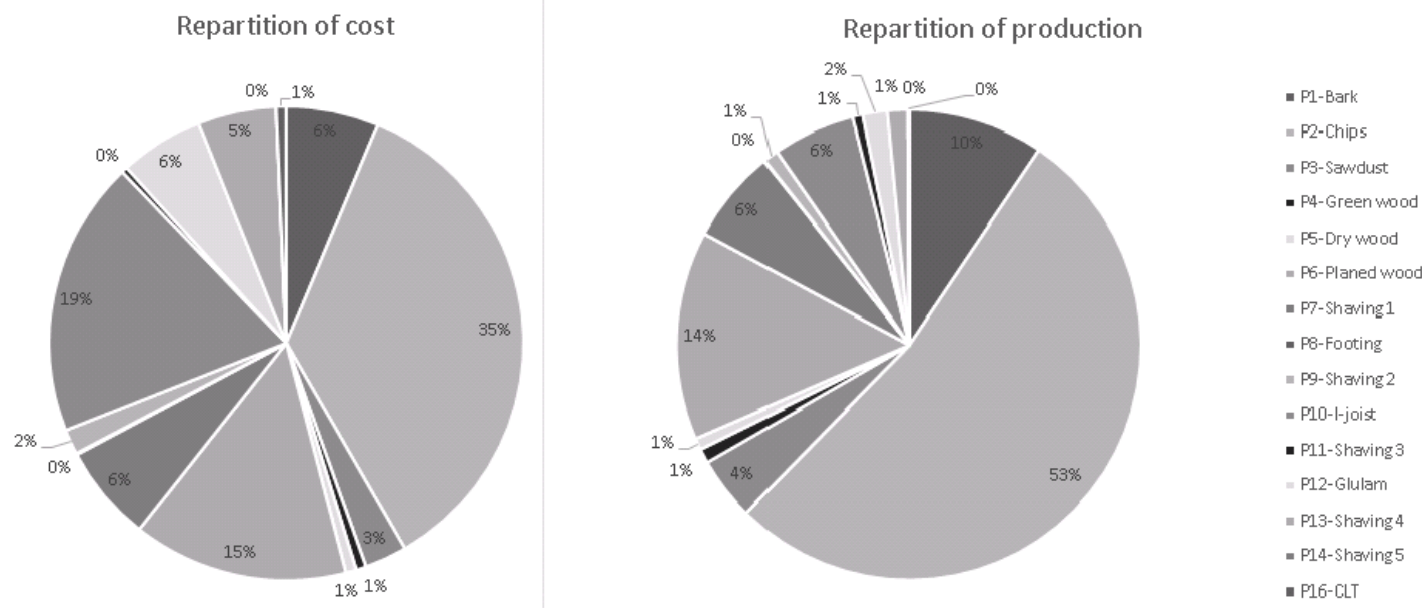

\section{Discussion}

First, it is important to distinguish the life cycle concepts presented previously because this terminology is used in several disciplines. The purpose of the analysis proposed in this section is to identify product development progress phases in the product portfolio to support the product's rolling strategy decision. To do this analysis, we use the Product Life Cycle (PLC), which is used in marketing and engineering to determine how mature a product is. Four steps are commonly used in PLC, as defined by Levitt (1965). These are (1) market development (or introduction), (2) growth, (3) maturity, and (4) decline.

The maturity of a product is defined primarily based on sales volumes (Barksdale \& Harris, 1982). Since the wood product market is mainly dependent on the North American residential building market and the EWP are still small we completed the analysis with available data on the technology investments, the profitability and the added value of wood products.

As PLC model alone is limited for strategic planning, this analysis is inspired by Barksdale and Harris (1982) and combines PLC and portfolio analysis. The aim is to situate the different products of the portfolio on the PLC curve in a strategic product portfolio management perspective. This analysis aims to initiate the technological succession planning. When a product is reaching the stage of decline, it is expedient to implement a new technology to develop an alternative product. This can also be performed with a circular economy perceptive, since co-products can be used as input for a new product. Thanks to the broad portfolio of products, the forest company can adjust production to the demand.

\subsection{Technology investments}

Investments on the development of new technologies or upgrades are an interesting indicator on the strategic positioning of products. Decision makers are the best placed to assess their investments. This study is based on the investments made by the CCltee, thus a micro-economic analysis. The trend in the global forest industry tends towards the development of engineering products (City of Prince George, 2017; Finnish Forest Industries, 2010; Woodco, 2013) and the CCltee 
are leaders in North America, by having launched the production of glulam in 2002, representing $15 \%$ of North American production (APA, 2014a).

Despite a difficult global economic situation that was holding back investments in the wood industry (Statistics Canada, 2015), CCltee has heavily invested in second and third transformation equipment over the past 30 years.

- the I-joist production line at the end of the 1990s and additional continuous investments to allows diversifying the dimensions of the I-joist.

- The laminating line in the beginning 2000s. The late 2000s, \$ 12 million was invested for the purchase of a CNC machine for the machining of large beams.

- At the beginning of the 2010, CCltee has designed and installed a CLT production line. It is a capital investment around 10 million Canadian dollars.

However, some investments have been made in last years in the first processing plant, to improve the productivity of sawing. It is a scanning system logs and optimization software, improving the efficiency of the high-speed saws. However, the level of investment remains well below compared with the tens of millions of dollars injected into the production of higher value-added products. Which clearly reflects the priority of CCltee to develop EWP.

\subsection{Profitability of products}

Profitability is the most important issue for a business, which makes it a key indicator in this PLC analysis. We calculated the distribution of the profitability of our partner product portfolio from average volumes and prices sales on the North American market. The selling price data of wood lumber, on the 2009 to 2012 period, used were from the RISI (2014) databases. The EWP selling price was funded in reports from Forest Economic Advisors (FEA, 2014) and the APA-The Engineering Wood Association (2014b).

Figure 6 shows the relative profitability of the main products of the portfolio. The relative benefit is the contribution to profits divided by the production volume. We used lumber as a reference. Thus, the profits generated by the sale of wood products are relative to lumber. In comparison with the reference, chips are a source of economic loss. Conversely, the EWP are between 3.5 and 5 times more profitable than lumber.

This analysis of profitability supports decision on which product should be taken as a priority to optimize and develop markets.

Figure 6: Relative profitability of the main products of the portfolio

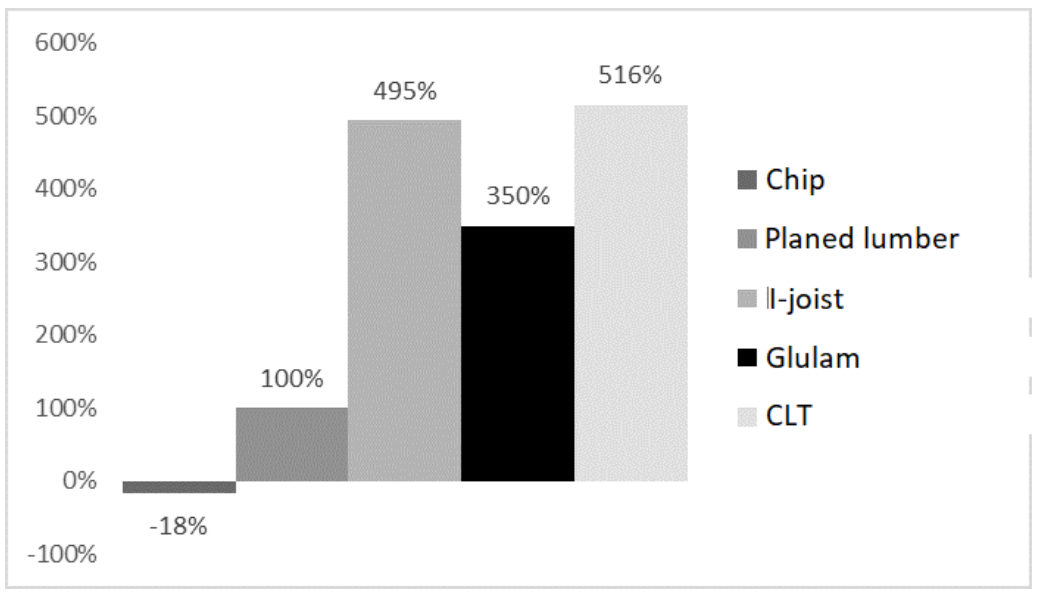

\subsection{Value added of wood products}

For confidentiality reasons we cannot present the added value of each of the products of the Ccltee portfolio. Therefore, we based the value added on macroeconomic data made available by the Canadian Government. Statistics Canada publishes data of value added of two large forest industry products: wood products and paper. Figure 7 presents the evolution of the added value of wood products and paper over ten years, from 2002 to 2012.

The wood products relate directly to our industrial partner. Lumber is part of the wood products category. Therefore, the I-joist, glulam and CLT are part of the secondary wood products. For paper products, the link to our partner is not direct, but chips as a by-product of the lumber industry are used as a primary material for the pulp and paper industry. From the volume of chips 
generated at the sawing activity (more than $50 \%$ of the total volume) and regarding the profitability of this by-product (figure 6), it is relevant to look at trends of the paper market.

Figure 7: Evolution of the added value of Canadian wood and paper products between 2002 and 2012

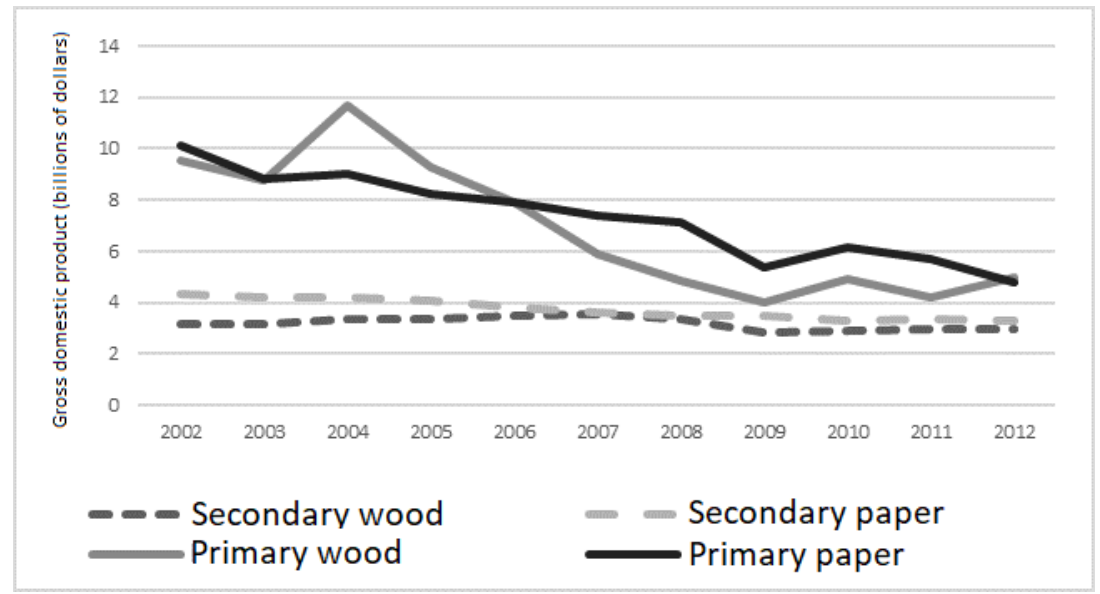

Source: Data NRCan, 2013

The first transformation wood products are strongly influenced by the market price of a residential building, and particularly by housing construction in the United States. As observed in the sensitivity analysis, price costs of harvesting activities are fairly stable. The fall of the added value of these products is correlated with the decline of the selling prices of lumber after a peak in 2004 . The slump continues with the crisis named "subprime". That resulted in a reduction of around $75 \%$ of new construction in the United States between 2005 and 2009 (Buehlmann \& Alderman, 2016).

Second transformation products have remained more stable than those from first transformation. The main reason is that EWP have a place on the Canadian market and on the nonresidential building market, making EWP less dependent of the United States housing market (RNCan, 2013).

Regarding paper products, the loss of value added is not only due to the 2008 economic crisis, but also due to a structural change arising from the development of electronic media, which led the decline of newsprint and printing papers (NRCan, 2013). In Canada, the production volume of paper rose from 27 million tons in 2000 and dropped to less than 17 million in 2009, representing a decrease of 36 percent in a decade. The Quebec province, where CCltee is located, is the largest global newsprint producer. According to the data provided by the Quebec Chips Producers Association [1], the price of chips is directly affected. Despite a greater stability, the production volume of the second transformation of the pulp and paper industry, such as envelopes, paper bags, does not compensate for this decline.

\subsection{Analysis of the wood product portfolio on the curve of product life cycle}

In order to ensure its sustainability, it is appropriate for a company to have a balanced portfolio regarding the product's life cycle, also called succession planning. It concerns diversifying the production by developing new technologies that will use the raw material of products that have reached the decline phase. The challenge is to maximize the long-term profit generated by the portfolio taking into account obsolescence and the growth dynamics of various products.

Inspired by Schuler and Adair (2003), we estimated the level of maturity of the main products of the CCltee portfolio. Based on the three indicators presented in this paper, and in cooperation with our industrial partner, we placed the main products of the portfolio on the product life cycle curve presented in the Figure 8. 
Figure 8: Distribution of the products portfolio in the life cycle curve

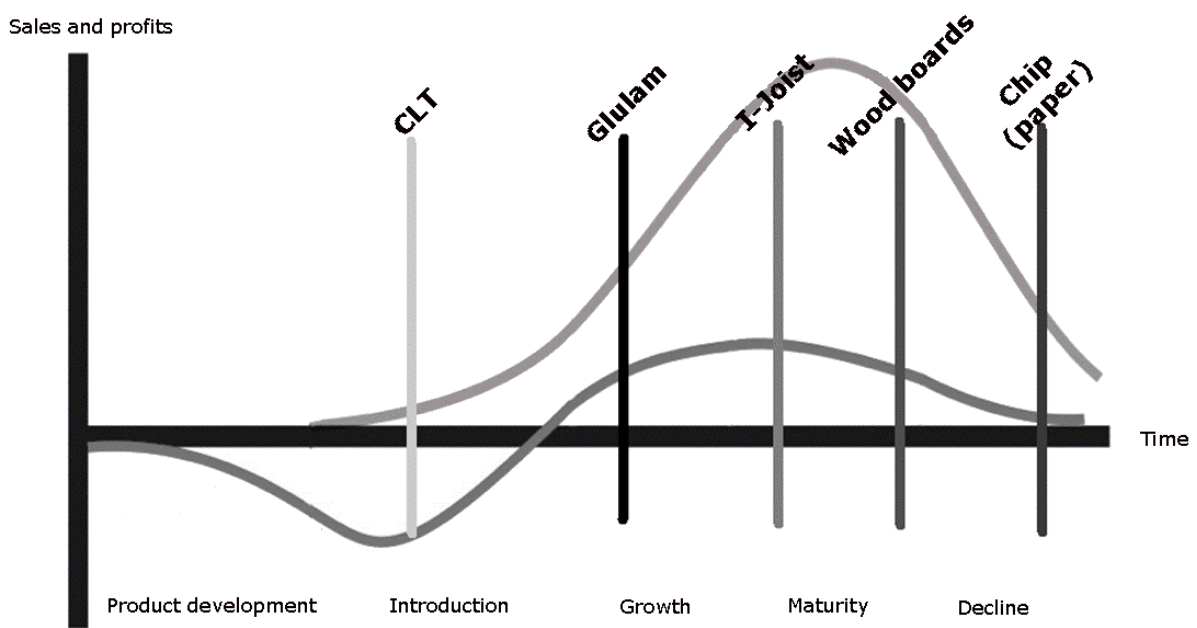

Source: inspired from Schuler and Adair, 2003

CLT is a product that has appeared in Europe in 1990's but was used in 2000's. It was introduced in North America after 2010 (RNCan, 2016). There are currently five CLT manufacturers in North America, and the CCltee is the only one on the East Coast. CLT is not yet profitable. A small volume is sold to date and that does not cover investments. When this product will make a breakthrough in the North American market, this will offer a promising potential development (reTHINKWOOD, 2015). Since 2014, few multi-story buildings in CLT are builted across North America (Pei et al., 2016). Based on these findings, we have placed the CLT in the introductory phase.

Schuler and Adair (2003) placed the glulam early in the growth phase. This product nibbled on the softwood lumber market share and accounted for $5 \%$ of the structural wood market, which justified the position. In the early 2000s, residential applications covered $65 \%$ of the North American glulam demand (APA, 2002). Then, wood products, and glulam in particular, used in non-residential buildings increased (Adair et al., 2013). Arguments in favor of wood used in buildings, such as climate change mitigation (Nabuurs et al. 2007) and the green economy development (United Nations et al., 2014), suggest the use will continue to increase in non-residential building. With a production of 339 million cubic meters in 2012, distributed in 38 plants in North America (AWC, 2015), glulam continues to grow.

In contrast to the two previous EWPs that are made-to-measure products, I-joists are standardized. There are various dimensions and quality, corresponding to the mechanical strength required. Since their introduction on the North American market in the beginning of the 1990s, sales have been continuously increasing (APA, 2002, 2008). This EWP is a structural component in nearly $50 \%$ of the dwellings housing floors (AWC, 2015). The production in North America has reached 155 million linear meters, in 2012, in 26 I-joist factories. This EWP has reached its level of maturity but I-joist can also pierce the non-residential market, as was suggested by Schuler and Adair (2003). Therefore, CCltee recently invested in the production line to use glulam instead of lumber with an increase in mechanical properties. This allows direct competing with steel products that dominate the non-residential market. This suggests EWP still have some development potential and that is why we put it at the beginning of the mature stage.

Green, dried and planned wood boards are grouped in the lumber category. This product family, mainly used for residential construction, represents the second-largest volume behind chips, with $16 \%$ of the total volume. Lumber is the flagship and main profit generator for sawmills. On the other hand, the decline of its added value and its dependency on the residential construction market in the United States suggests this product has passed the peak of profitability and therefore it is advanced in its maturity phase.

The situation of chip is more complex. Considered by the sawing industry as a by-product, the chips are sold to the highest bidder from the pulp and paper industry. The sale revenue is subtracted from the cost price of lumber (Rappold, 2006). As described in the value-added section, paper products are in decline. On the other hand, the number of opportunities for lignocellulose material explodes and affects many sectors since chips can be used as feedstock for many bioenergy and biobased material applications (FPAC, 2011). As shown by Chornet (2005), there is a link between the consumption and the market price. As an example, taxane is used by the pharmaceutical industry and has a very high value, but the volume consumed is limited. In contrast, the wood used for energy production has an almost infinite potential, but to a much lower price. Thus, there is potential to 
increase the number of products in the portfolio. By considering the chips as a co-product, profits generated by their sale are well below the lumber reference. That allows us to place chips, destined for the paper industry, in an advanced stage of decline. However, new opportunities can be explored for this material.

As shown in the figure 8, the portfolio products are well distributed over the life cycle curve. Three EWPs are early in the cycle, in accordance with the indicator assessment. Lumber has reached the mature stage. Then chips, destined for the paper industry, is a product in the decline phase. The CCltee is an example in terms of product portfolio management. To keep this status, they must stay proactive, by developing continuously and not only products but also of sales strategies. Actually, CCltee opened a subsidiary, called Nordic Structure, which provides technical support to architects and engineers. This development allows Ctlee to no longer be a convenience seller, but a vendor of wood building systems. Thereby increasing the value added of their product portfolio.

\section{Conclusion}

This paper presents the application of an Activity-Based Life Cycle Costing on the overall operations of harvesting and processing of a forestry company which is the first published. In addition, our industrial partner, CCltee, is an innovative sawmill which manufacture also engineered wood products, which provides a diversified product portfolio. The AB-LCC was used to calculate the cost of each activity and then the price costs of each product of the portfolio, with a volumetric allocation presented in the methodology section. The interest to use a physical allocation is to consider all products as having development potential, without the influence of the present prices on the market. It provides the most objective possible information for strategic decision-making.

In the discussion, we assessed the level of maturity of the products through a case study. This analysis is based on a valuation of investments, profitability and value added, in addition to the costs of returns and the allocation of production volume of the portfolio. The interest to assess the level of maturity for a portfolio is to plan the succession of the products that reached the decline phase. To complete this analysis, other fundamental aspects of the product life cycle such as the duration, the amplitude and the speed of growth could be taken into account in a forthcoming study. As also shown by Beauregard and D'Amours (2003), all building products don't have the same penetration rate on the market and life expectancy. A priori, this has a not negligible influence on succession planning.

The number of wood products is growing. The lignocellulose material is used in many sectors, such as chemistry, pharmaceutics, energy, and construction. In addition, it was shown by the Intergovernmental Panel on Climate Change (IPCC) that wood product processing is less energy intensive and emits less greenhouse gases than non-wood building materials. The use of wood instead of fossils as product resource, also for energy purposes, provides a net reduction of greenhouse gas emissions (Nabuurs et al., 2007). The diversification of the use and the environmental benefits of wood products are expected to increase the interest in this renewable material.

The forest industry is divergent. It has the advantage of an already large portfolio of products to manage and control a complex supply chain, all for huge volumes. In addition, the forest industry has the advantage of being able to use its own co-products as a resource. Shavings combustion as an energy source for drying activity, as presented in the case study, is quite common. Other uses are also considered, such as the production of cellulosic biodiesel to drive forest machines or the extraction of lignin to be applied as glue would be concrete applications in a circular economy.

All these advantages, despite challenges ahead, lead us to believe that the forestry industry has the potential to play a key role in the sustainable economy of the future, even if the marketing of new materials is a long and perilous process. How these challenges are dealt will make the difference between success and failure (Boren et al., 2012). It is important that decision-makers take wiser choices that match the context more accurately and do not only take into account the economic aspects in the short term. Wood products have the potential to be an example of application of the principles of sustainable development.

\section{Acknowledgments}

We thank our industrial partner, the CCltee for their trust and for having shared their data. In particular Pascal Ouellet and Frédéric Verreault, who took the time to respond to our requests. We also thank the financial support of the FQRNT and the FORAC research consortium. 


\section{Funding}

The financial support of the FQRNT and the FORAC research consortium.

\section{Citation information}

Laurent, A.-B., Beauregard, R., \& D'amours, S. (2021). Activity-Based Life-Cycle Costing applied to an innovative forestry company product portfolio. Economics, Management and Sustainability, 6(1), 6-26. doi:10.14254/jems.2021.6-1.1.

\section{Reference}

Adair, C., McKeever, D. B., Gaston, C., \& Stewart, M. (2013). Wood and other materials used to construct nonresidential buildings in the United States 2011 (p. 127). Home Innovation Research Labs. http://www.fpl.fs.fed.us/documnts/pdf2013/fpl_2013_adair001.pdf

Ainsworth, P., \& Deines, D. (2003). Introduction to accounting an integrated approach. McGraw/Irwin,2003 3RD EDITION.

Alemdag, I. S. (1982). Biomass of the merchantable and unmerchantable portions of the stem (p. 25). Petawawa National Forestery Institute, Canadian Forestery Service, Environment Canada. http://cfs.nrcan.gc.ca/entrepotpubl/pdfs/4475.pdf

Anderson, S. W., Hesford, J. W., \& Young, S. M. (2002). Factors influencing the performance of activity based costing teams: A field study of $\mathrm{ABC}$ model development time in the automobile industry. Accounting, Organizations and Society, 27(3), 195-211. https://doi.org/10.1016/S03613682(01)00057-5.

APA. (2002). Market Outlook-Lumber, Structural Panels, and Engineered Wood Products (p. 57). The Engineered Wood Association.

APA. (2008). Structural Panels and Engineered Wood. https://www.apawood.org/Data/Sites/1/documents/marketresearch/2008-QuarterlyEngWoodStats.pdf

APA. (2014a). Structural Panel and Engineered Wood Yearbook (No. MKOE180). The Engineered Wood Association.

APA. (2014b). https://www.apawood.org/

Asiedu, Y., \& Gu, P. (1998). Product life cycle cost analysis: State of the art review. International Journal of Production Research, 36(4), 883-908. https://doi.org/10.1080/002075498193444

AWC. (2015). American Wood Council. http://www.awc.org/

Barksdale, H. C., \& Harris, C. E. (1982). Portfolio analysis and the product life cycle. Long Range Planning, 15(6), 74-83. https://doi.org/10.1016/0024-6301(82)90010-3

Beauregard, R., \& D’Amours, S. (2003, Décembre). Une stratégie de prestation de service adaptée à chacune des étapes du cycle de vie d'un produit. Penser client, Québec, Canada.

Berliner, C., \& Brimson, J. A. (1988). Cost Management for Today's Advanced Manufacturing: The CamI Conceptual Design. Harvard Business School Press.

Boren, M., Chan, V., \& Musso, C. (2012, August). The path to improved returns in materials commercialization. Mc Kinsley on Chemicals, 12-20.

Briggs, D. G. (1994). Forest Products Measurements and Conversion Factors: With Special Emphasis on the U.S. Pacific Northwest. University of Washington Institute of Forest Resources.

Bruggeman, W., Everaert, P., Anderson, S. R., \& Levant, Y. (2005). Modeling Logistics Costs using TimeDriven ABC: A Case in a Distribution Company (Working Papers of Faculty of Economics and Business Administration, Ghent University, Belgium No. 05/332). Ghent University, Faculty of Economics and Business Administration. http://ideas.repec.org/p/rug/rugwps/05-332.html

Chornet, E. (2005, November). Thermochemical Strategies for Biofuels, Green Chemicals, Polymeric Biomaterials and Biofuels. 
City of Prince George. (2017). Opportunity profile-Engineered Wood Products. https://princegeorge.ca/Business\%20and\%20Development/Economic\%20Development\%2 0Documents/Engineered_Wood_Products_Opp_Profile_\%28WEB\%29.PDF

Cooper, R., \& Kaplan, R. S. (1988, September). Measure Costs Right: Make the Right Decisions. Harvard Business Review. https://hbr.org/1988/09/measure-costs-right-make-the-right-decisions

Durairaj, S. K., Ong, S. K., Nee, A. Y. C., \& Tan, R. B. H. (2002). Evaluation of Life Cycle Cost Analysis Methodologies. Corporate Environmental Strategy, 9(1), 30-39. https://doi.org/10.1016/S1066-7938(01)00141-5

Emblemsvåg, J. (2003). Life-Cycle Costing: Using Activity-Based Costing and Monte Carlo Methods to Manage Future Costs and Risks. John Wiley \& Sons.

FEA. (2014). https://www.getfea.com/

$\begin{array}{llll}\text { Finnish } & \text { Forest } & \text { Industries. }\end{array}$ https://www.metsateollisuus.fi/uploads/2017/03/30041738/885.pdf

Flann, I. B. (1962). Certains facteurs de conversion et renseignements connexes, à l'intention de l'industrie forestiéres de l'est $d u$ Canada (No 1070F). Minsitére des forêts. http://cfs.nrcan.gc.ca/pubwarehouse/pdfs/24560.pdf

FPAC. (2011). Le nouveau visage de l'industrie forestière canadienne: Une biorévolution en devenir Le Projet de la voie biotechnologique (p. 12). Association des produits forestiers du Canada. http://www.fpac.ca/wp-content/uploads/publications/fr/avenir/BIOPATHWAYS-II-FRweb.pdf

Frayret, J.-M., D’Amours, S., Rousseau, A., Harvey, S., \& Gaudreault, J. (2008). Agent-based supplychain planning in the forest products industry. International Journal of Flexible Manufacturing Systems, 19(4), 358-391. https://doi.org/10.1007/s10696-008-9034-Z

Gervais, M., Levant, Y., \& Ducrocq, C. (2010). Le Time-Driven Activity-Based Costing (TDABC):un premier bilan à travers une étude de cas longitudinale. Revue Finance Contrôle Stratégie, 13(1), 123-155.

Gluch, P., \& Baumann, H. (2004). The life cycle costing (LCC) approach: A conceptual discussion of its usefulness for environmental decision-making. Building and Environment, 39(5), 571-580. https://doi.org/10.1016/j.buildenv.2003.10.008

Hachez, E. (2006). Calcul du prix de revient. Edipro.

Haygreen, J. G., \& Bowyer, J. L. (1989). Forest Products and Wood Science: An Introduction. Iowa State University Press.

Institut Bauen und Umwelt e.V. (2009). PCR Wood Materials. www.bau-umwelt.com

Jeges, R. (2008). The Monte Carlo method - ProjectWare. http://www.projectware.com.au/themonte-carlo-method/

Jessome, A. P. (1977). Strength and related properties of woods grown in Canada (Eastern Forest Products Laboratory). http://www.torontopubliclibrary.ca/detail.jsp?Entt=RDM1951017\&R=1951017

Johnson, H. T., \& Kaplan, R. S. (1991). Relevance Lost: The Rise and Fall of Management Accounting. Harvard Business Press.

Kaplan, R. S., \& Anderson, S. R. (2007). The Innovation of Time-Driven Activity-Based Costing. http://www.hbs.edu/faculty/Pages/item.aspx?num=24208

Korpunen, H., Mochan, S., \& Uusitalo, J. (2010). An activity-based costing method for sawmilling. Forest Products Journal. http://www.highbeam.com/doc/1G1-246347197.html

Laurent, A.-B., Menard, J.-F., Lesage, P., \& Beauregard, R. (2016). Cradle-to-Gate Environmental Life Cycle Assessment of the Portfolio of an Innovative Forest Products Manufacturing Unit. BioResources, 11(4), 8981-9001. https://doi.org/10.15376/biores.11.4.8981-9001

Lere, J. C. (2000). Activity-based costing: A powerful tool for pricing. Journal of Business \& Industrial Marketing, 15(1), 23-33. https://doi.org/10.1108/08858620010311539 
Luo, L., van der Voet, E., \& Huppes, G. (2009). Life cycle assessment and life cycle costing of bioethanol from sugarcane in Brazil. Renewable and Sustainable Energy Reviews, 13(6-7), 1613-1619. https://doi.org/10.1016/j.rser.2008.09.024

Maher, M. W., \& Deakin, E. (1991). Cost Accounting. Irwin Professional Publishing.

Malcom, R. E. (1991). Overhead Control Implications of Activity Costing. Accounting Horizons, 5(4), 69.

Meil, J., Bushi, L., Garrahan, P., Aston, R., Gingras, A., \& Elustondo, D. (2009). Status of Energy Use in the Canadian Wood Products Sector (No. 6014). FPInnovations - Forintek Division.

Metropolis, N., \& Ulam, S. (1949). The Monte Carlo Method. Journal of the American Statistical Association, 44(247), 335-341.

Nabuurs, G. J., Masera, O., Andrasko, K., Benitez-Ponce, P., Boer, R., Dutschke, M., Elsiddig, E., FordRobertson, J., Frumhoff, P., Karjalainen, T., Krankina, O., Kurz, W. A., Matsumoto, M., Oyhantcabal, W., Ravindranath, N. H., Sanz Sanchez, M. J., \& Zhang, X. (2007). Forestry. In Climate Change 2007: Mitigation. Contribution of Working Group III to the Fourth Assessment Report of the Intergovernmental Panel on Climate Change [B. Metz, O.R. Davidson, P.R. Bosch, R. Dave, L.A. Meyer (eds)]. Cambridge University Press, Cambridge, United Kingdom and New York, NY, USA.

Nielson, R. W., Wright, D. M., \& Dobie, J. (1985). Conversion factors for the forest products industry in Western Canada. Forintek Canada Corp., Western Laboratory.

Nurminen, T., Korpunen, H., \& Uusitalo, J. (2009). Applying the activity-based costing to cut-to-length timber harvesting and trucking. Silva Fennica, 43(5), 847-870.

Pei, S., Rammer, D., Popovski, M., Williamson, T., Line, P., \& Lindt, J. W. van de. (2016). An Overview of CLT Research and Implementation in North America. In: WCTE 2016, August 22-25, 2016 Vienna, Austria. https://www.fs.usda.gov/treesearch/pubs/52580

Posavec, S., Zelić, J., Fliszar, I., \& Beljan, K. (2011). Implementation of Cost Calculation Model in Forest Evaluation of Požega Forest Administration. Croatian Journal of Forest Engineering, 32(1), 466, $457-467,466$.

Rappold, P. M. (2006). Activity-based product costing in a hardwood sawmill through the use of discrete-event simulation [Virginia Polytechnic Institute and State University]. http://scholar.lib.vt.edu/theses/available/etd-06122006-162052/

reTHINKW0OD. (2015). Tall Wood / Mass Timber / ReThink Wood. http://www.rethinkwood.com/masstimber/mass-timber-manufacturers

RISI. (2014). http://www.risiinfo.com/

RNCan. (2016). Panneaux lamellés-croisés / Ressources naturelles Canada. Ressources Naturelles Canada. http://www.rncan.gc.ca/forets/industrie/demandes/15830

RNCan, R. N. C. (2013). Seconde transformation / Ressources naturelles Canada. https://www.rncan.gc.ca/forets/rapport/industrie-changement/16543

Schindler, M. (2008). Measuring Financial Integration: A New Data Set. IMF Staff Papers, 56(1), 222238. https://doi.org/10.1057/imfsp.2008.28

Schuler, A., \& Adair, C. (2003). Engineered and Other Wood Products-An Opportunity to "Grow the Pie" (pp. 43-53). http://www.treesearch.fs.fed.us/pubs/7952

Statistics Canada. (2015). Forestry and Logging (NAICS 113): Capital investment - Canadian Industry Statistics - Industries and Business - Industry Canada [Report]. https://www.ic.gc.ca/app/scr/sbms/sbb/cis/capitalInvestment.html?code=113\&lang=eng

The Norwegian EPD Foundation. (2013). Product-Category Rules: Wood and wood-based products for use in construction. norge.no/getfile.php/PDF/PCR/NPCR\%20015\%20Wood\%20and\%20woodbased $\% 20$ products $\% 20$ for\%20use $\% 20 \mathrm{in} \% 20$ construction.pdf

United Nations, Food and Agriculture Organization of the United Nations, \& United Nations (Eds.). (2014). Rovaniemi Action Plan for the forest sector in a green economy. United Nations. 
Wessels, C. B., \& Vermaas, H. F. (1998). A management accounting system in sawmilling using activity based costing techniques. The Southern African Forestry Journal, 183(1), 31-35. https://doi.org/10.1080/10295925.1998.9631198

Woodco. (2013). Prosperity from Forestry and Wood Products. Wood council of NZ inc. http://www.nzffa.org.nz/system/assets/1589/industry_manifesto_060314pdf.pdf

Woodward, D. G. (1997). Life cycle costing-Theory, information acquisition and application. International Journal of Project Management, 15(6), 335-344. https://doi.org/10.1016/S0263-7863(96)00089-0

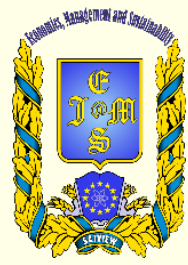

(c) 2016-2021, Economics, Management and Sustainability. All rights reserved.

This open access article is distributed under a Creative Commons Attribution (CC-BY) 4.0 license.

You are free to:

Share - copy and redistribute the material in any medium or format Adapt - remix, transform, and build upon the material for any purpose, even commercially.

The licensor cannot revoke these freedoms as long as you follow the license terms.

Under the following terms:

Attribution - You must give appropriate credit, provide a link to the license, and indicate if changes were made.

You may do so in any reasonable manner, but not in any way that suggests the licensor endorses you or your use.

No additional restrictions

You may not apply legal terms or technological measures that legally restrict others from doing anything the license permits.

Economics, Management and Sustainability (ISSN: 2520-6303) is published by Scientific Publishing House "CSR", Poland, EU and Scientific Publishing House "SciView", Poland

Publishing with JEMS ensures:

- Immediate universal access to your article on publication

High visibility and discoverability via the JEMS website

- Rapid publication

- Guaranteed legacy preservation of your article

- Discounts and waivers for authors in developing regions

Submit your manuscript to a JEMS at http:///iems.sciview.net or submit.jems@sciview.net 